\title{
SECTION 346 OF THE INTERNAL REVENUE CODE : A LEGISLATIVE ENIGMA
}

\author{
FERdinand P. Sohoetute, JR. $\dagger$
}

Although the Internal Revenue Code of 1954 has not yet survived its first decade and cases construing many of its provisions are just beginning to reach the courts, Congressman Mills, chairman of the House Committee on Ways and Means, has already called for aid in proposing a complete revision of the Code. Among the Code's provisions for which revision has been suggested is section 346 , the so-called corporate contraction section. That provision, through its definition of section 331's "partial liquidation," provides for capital gains treatment of certain corporate distributions to shareholders "characterized by what happens solely at the corporate level by reason of the assets distributed . . ."1 When enacted, section 346 was intended to codify existing law.

Despite the tenure of the concept of a corporate contraction as an event giving rise to taxation at other than ordinary income rates, the validity of the principles which section 346 attempts to articulate has been repeatedly attacked on the ground that "the corporate contraction" is a concept without meaning: the distributions in question are usually pro rata among the shareholders, and the effect of allowing taxation at capital gains rates is to provide an avenue for the avoidance of tax. These critics suggest elimination rather than revision of the corporate contraction concept. ${ }^{2}$ The proposed statutory changes, however, not only perpetuate the concept, but seem to contemplate its increased vigor.

This Article will first analyze the pre-1954 statutory and case law with a view to posing the problem which faced Congress in 1954 and will then consider section 346 itself. Finally, the proposed modifications and other legislative schemes will be investigated.

† A.B. 1955, Princeton University; LL.B. 1960, Harvard Law School. Law Clerk to Judge Learned Hand of the United States Court of Appeals for the Second Circuit.

1 S. Rep. No. 1622, 83d Cong., 2d Sess. 49 (1954).

2 Bittker \& Redlich, Corporate Liquidations and the Income Tax, 5 TAX L. REv. 437, 472-73 (1950); Cohen, Surrey, Tarleau \& Warren, A Technical Revision of the Federal Income Tax Treatment of Corporate Distributions to Shareholders, 52 Couvm. L. REv. 1, 37-38 (1952). 


\section{Statutory and Case Law Development}

\section{The Legislative Genesis of Section 346}

Section 346 had its legislative origin in a series of general statutes directed to determining the proper taxation of distributions from a corporation to its shareholders. Prior to 1924 no statutory reference was made to partial liquidations as such. The Revenue Act of 1913 taxed "dividends" but failed to define the term." Supreme Court decisions indicated, however, that a complete liquidation was not a dividend ${ }^{4}$ and intimated that transactions where stock was surrendered might be considered differently from situations where this factor was not present. 5 The 1916 act defined "dividend" as any distribution out of post-1913 earnings and profits and thus seemingly obviated any other treatment when property passed from a prosperous corporation to its stockholders. ${ }^{6}$ Despite this all-inclusive definition, however, it is not clear that the Treasury actually utilized this approach when stock was surrendered in return for funds. This can be illustrated by reference to Treasury practice under the Revenue Acts of 1918 and 1921.

The 1918 act made no provision for partial liquidations, but provided that amounts distributed in the liquidation of a corporation were to be treated as payments "in exchange" for stock. ${ }^{\top}$ The Revenue Act of 1921 merely stated that any distribution from earnings and profits was a dividend. ${ }^{8}$ Treasury practice, if not the tax rates, with respect to partial liquidations was the same under both these acts. Until 1936, dividends were subject to the surtax but not to the normal tax, ${ }^{9}$ probably on the theory that the earnings and profits of the corporation had already been taxed once at the corporate level and should not be subject to a double tax. With partial liquidations the Treasury regarded only the gain as taxable, evidently assuming that the taxpayer was entitled to a return of his basis of the stock redeemed. ${ }^{10}$ Under this last assumption it would have been possible under both the 1918 and 1921 Revenue Acts for the stockholder to contend that the entire distribution should be taxed to him at the dividend (surtax) rate, but

3 Tariff Act of 1913, ch. 3, §2(b), 38 Stat. 167.

4 Lynch v. Turrish, 247 U.S. 221 (1918).

5 Cf. Lynch v. Hornby, 247 U.S. 339, 341 (1918).

6 Revenue Act of 1916 , ch. 463, $\$ 2$ (a), 39 Stat. 757.

7 Revenue Act of 1918, ch. 18, $\$ 201$ (c), 40 Stat. 1059.

8 Revenue Act of 1921, ch. 136, §201(c), 42 Stat. 228.

9 Revenue Act of 1921, ch. 136, §216(a), 42 Stat. 242.

10 I.T. 1543, II-I Cum. Bul. 17 (1923) (Revenue Act of 1921) ; A.R.M. 93, 3 Cum. Bull. 40 (1920) (Revenue Act of 1918). See Kurz, Partial Liquidations of Corporations-An Analysis, National Income Tax Magazine, July 1924, p. 199; Magill, The Income Tax Liability of Dividends in Liquidation, 23 Micm. L. Rev. 565, 579,584 (1925). 
that the basis of the stock should be allowed as a deduction against income subject to both normal and surtax rates. ${ }^{11}$ Under the 1921 act it seems clear that the gain involved was taxed at only the surtax rate; ${ }^{12}$ under the 1918 act Treasury practice was to tax the gain as a "part liquidation" at the exchange (normal and surtax) rate. $^{13}$ Whether this latter treatment was authorized by the statute is open to question. $^{14}$

Whatever the legislative sanction for taxing gains in "part liquidation" at the nondividend rate, the stockholder during this early period was able to utilize the partial liquidation in order to withdraw funds from the corporation without the payment of any tax. Although the Treasury has attempted to maintain the logically impeccable position that the stock surrendered in a partial liquidation should bear a correlation to the assets distributed, and has been successful with this position in the Tax Court, ${ }^{15}$ it seems probable that throughout this entire period-and indeed perhaps today also ${ }^{16}$ - the stockholder controlled not only the selection of high or low basis stock for redemption but also the number of shares to be redeemed. Thus "gain" could be avoided to a large extent.

The Revenue Act of 1924 sanctioned prior Treasury practice by providing that partial and complete liquidations were to be taxed as "in exchange," thus making them-as a usual rule-subject to both the normal tax and the surtax. ${ }^{17}$ But under section 208 the taxpayer was able to limit his capital gains rate to 12.5 per cent; ${ }^{18}$ thus a partial liquidation might for the wealthy stockholder produce a better result than a dividend, which might be subject, as ordinary income, to a surtax rate in excess of 12.5 per cent.

Taxation of the gain from partial liquidations at capital gain rates continued until the Revenue Act of 1934, which provided that gains in partial and complete liquidations should be taxed as short-

11 Magill, supra note 10; cf. Commissioner v. Sansome, 60 F.2d 931 (2d Cir.), cert. denied, 287 U.S. 667 (1932).

12 I.T. 1543, II-1 Cum. BuLL. 17 (1923).

13 A.R.M. 93, 3 CUM. Bull. 40 (1920) (taxing as "income") ; O.D. 479, 2 CUM. BULL. 29 (1920) (taxing as "sale" in "part liquidation") ; O.D. 488, 2 CUM. BULI. 29 (1920). The Treasury Regulations were equivocal and did not seem to deal with partial liquidations. Treas. Reg. 45, art. 1548 (1920), as amended, T.D. 3206, 5 CuM. BuLL. 46 (1921).

14 The statutory phrase "amounts distributed in the liquidation" might have been strictly construed to avoid "double taxation" in those situations, such as partial liquidations, where the language was not clearly applicable. C f. Hellmich v. Hellman, 18 F.2d 239 (8th Cir. 1927), rev'd, 276 U.S. 233 (1928).

15 Malone v. Commissioner, 128 F.2d 967 (5th Cir. 1942), reversing 45 B.T.A. 305

(1941); Orie R. Kelly, 36 B.T.A. 507 (1937), rev'd, 97 F.2d 915 (2d Cir. 1938).

16 See, e.g., Joseph W. Imler, 11 T.C. 836 (1948).

17 Revenue Act of 1924, ch. 234, §201(c), 43 Stat. 255.

18 Revenue Act of 1924, ch. 234, §208, 43 Stat. 262. 
term capital gains. ${ }^{19}$ The reason advanced for this treatment was that wealthy shareholders had been able to avoid the surtax rates through resort to favorable capital gains treatment. ${ }^{20}$ The committee report noted, however, that the matter was disputable since distributions in liquidation contained some of the characteristics of sales as well as of dividends. ${ }^{21}$ Though the 1936 act restored complete liquidations to capital gain status, ${ }^{22}$ it was not until 1942 that similar treatment was extended to partial liquidations. ${ }^{23}$ In making the 1942 change, the committee noted that the short-term capital gain treatment had been originally adopted to prevent ordinary dividends from being distributed at capital gains rates. It expressed a belief that section $115(\mathrm{~g})$ of the act would suffice to prevent "distributions in partial liquidation from being utilized to disguise the taxation of a taxable dividend." 24

The section to which the committee referred provided for dividend treatment of distributions in partial liquidation when a corporation cancelled or redeemed its stock in "such manner as to make the distribution . . essentially equivalent to a distribution of a taxable dividend." 25 Although this section was contained in the same portion of the statute as the liquidation provisions discussed above and would seem to have provided a ready guide in the interpretation of "partial liquidation," such was not the case. Section $115(\mathrm{~g})$ had its origins in the problems presented by Eisner v. Macomber ${ }^{26}$ and was not initially conceived as a corollary to the treatment of partial liquidations. After the Court held in Eisner that a stock dividend could not be taxed, Congress-apparently concerned that a corporation could distribute a "tax free" stock dividend and subsequently redeem stock-provided in section 201(d) of the Revenue Act of 1921 that redemption of stock subsequent to a stock dividend would be subject to dividend taxation where such redemption was "essentially equivalent" to a dividend. ${ }^{27}$ Section 201 (d) seems to have been ill-conceived inasmuch as the prior issuance of a stock dividend has little, or nothing, to do with the question of benefit to the shareholder upon redemption of stock: a stock dividend itself adds nothing to a shareholder's claim, and the

19 Revenue Act of 1934, ch. 277, $\$ 115$ (c), 48 Stat. 711.

20 H.R. REP. No. 704, 73d Cong., 2d Sess. 29 (1934); S. REP. No. 558, 73d Cong., $2 d$ Sess. 37 (1934).

21 Ibid.

22 Revenue Act of 1936, ch. 690, $\S 115$ (c), 49 Stat. 1687.

23 See Revenue Act of 1942, ch. 619, \& 147, 56 Stat. 841.

24 H.R. REP. No. 2333, 77th Cong., $2 d$ Sess. 49 (1942); S. REP. No. 1631, 77th Cong., 2d Sess. 116 (1942).

25 Int. Rev. Code of 1939, ch. 1, $\$ 115(\mathrm{~g}), 53$ Stat. 48.

26252 U.S. 189 (1920).

27 Revenue Act of 1921, ch. 136, § 201(d), 42 Stat. 228. 
existence vel non of a stock dividend prior to a redemption does not affect either the amount of cash received by the shareholder or his proportionate interest in the corporation following the redemption.

The Revenue Act of 1924 did nothing to clarify this situation when it provided that a redemption would be subjected to the criterion of "dividend equivalency" when made "before or after" the distribution of a stock dividend. ${ }^{28}$ In the 1926 act, both section $201(\mathrm{~g})$ and its legislative history seemed to reflect a congressional understanding of the method by which a partial liquidation could achieve the same effect as a dividend. The section provided that partial liquidations were to be treated as dividends whenever "essentially equivalent" thereto; ${ }^{29}$ and the legislative history expressed an intent to prevent tax avoidance and gave a hypothetical case to aid in future interpretation. ${ }^{30}$

\section{The Treasury Regulations}

This post-1926 statutory scheme seemed to be conducive to the development of well-elaborated treasury regulations which would aid counsel and courts in the application of such general criteria as whether a distribution was "essentially equivalent to the distribution of a taxable dividend." Unfortunately, no such regulations were ever promulgated. Those originally promulgated under the Revenue Act of 1926 were of no aid, merely reciting that the determination was one which depended "upon the circumstances of each case." 31 Regulations published in 1931 offered some help by attempting to identify the polar cases. They said that cancellation of stock pro rata would "generally be considered as effecting a distribution essentially equivalent to a

28 Revenue Act of 1924, ch. 234, $\$ 201$ (f), 43 Stat. 255. On its face "before or after" could have been broadly construed. However, the legislative history clearly supported a narrow construction. H.R. REp. No. 179, 68th Cong., 1st Sess. 12, 49 (1924); S. Rep. No. 398, 68th Cong., 1st Sess. 13 (1924); Staff of the Senate Comm. on Finance, 68rh Cong., 1st Sess., Statement of Changes Made in the Revenue ACt of 1921 by H.R. 6715 and the Reasons Therefor 4 (Comm. Print 1924).

29 Revenue Act of 1926, ch. $27, \S 201(\mathrm{~g}), 44$ Stat. 11.

30 H.R. Rep. No. 1, 69th Cong., 1st Sess. 5 (1925). The report said: "It has been contended that under existing law a corporation, especially one which has only a few stockholders, might be able to make a distribution to its stockholders which would have the same effect as a taxable dividend. For example: Assume that two men hold practically all the stock in a corporation, for which each had paid $\$ 50,000$ in cash, and the corporation had accumulated a surplus of $\$ 50,000$ above its cash capital. It is claimed that under existing law the corporation could buy from the stockholders, for cash, one-half of the stock held by them and cancel it without making the stockholders subject to any tax. Yet this action, in all essentials, would be the equivalent of a distribution through cash dividends of the earned surplus. The amendment proposed to this subdivision is intended to make clear that such a transaction is taxable." See also S. REP. No. 52, 69th Cong., 1st Sess. 15 (1926).

31 Treas. Reg. 69, art. 1549 (1926). 
dividend distribution," and that complete termination of a shareholder's interest did "not effect a distribution of a taxable dividend." 32 Because of the anemia of the term "generally" and the regulations' further statement that the determination was one to be made "upon the circumstances of each case," these regulations-which remained substantially unchanged until $1954^{33}$-provided little guidance for the courts.

\section{Partial Liquidation in the Courts}

As can be expected from the confusing circumstances attending the enactment of section $201(\mathrm{~g})$ of the Revenue Act of 1926, the courts experienced extreme difficulties in determining which partial liquidations to treat as dividends. From 1934 to 1942 -when partial liquidations were not subject to favorable tax status-the courts, in addition to determining dividend equivalency, concerned themselves with the question of whether every situation where a stockholder surrendered stock to his corporation was a partial liquidation or whether the taxpayer might not be deemed to have "sold" the stock. Many courts did indicate that a stockholder could "sell" stock to his corporation. $^{34}$ The approach, once adopted, might have been utilized to develop criteria similar to those contained in present section $302 .^{35}$ However, no such criteria were evolved; instead the irrelevant distinction between stock that was cancelled and that held as treasury stock was made determinative of tax consequences. It is questionable whether there was any rational basis for considering treasury stock as having been sold; ${ }^{36}$ certainly there does not seem to have been any justification in the statutory language. Fortunately, this distinction, once adopted and carried to its ultimate extreme, appears to have been finally rejected. ${ }^{37}$

32 Treas. Reg. 74, art. 629 (1931) (issued under the Revenue Act of 1928).

33 Compare ibid. with Treas. Reg. 118, §39.115(g)-1(a) (1953).

34 See, e.g., Amelia H. Cohen Trust v. Commissioner, 121 F.2d 689, 691 (3d Cir. 1941) (dictum).

35 In Phelps v. Commissioner, 54 F.2d 289, 292 (7th Cir. 1931), cert. denied, 285 U.S. 558 (1932), the Seventh Circuit distinguished the case on appeal, where the stock had been redeemed pro rata, from a hypothetical case where a single stockholder disposed of his shares to the corporation by indicating that in such a case there would be no intention of all the shareholders to liquidate. William A. Smith, 38 B.T.A. 317 (1938), acq., 1939-2 CuM. BuLL. 34, withdrazving previous nonacq. in 1939-1 Cum. Bull. 63, was a case such as that hypothesized in Phelps. The Board quoted the Phelps dictum but relied primarily on the fact that the stock in the case before it was carried as treasury stock after its acquisition by the corporation which had not been the case in Phelps.

36 One author felt that it was not a wholly irrational distinction during the period when corporations carried treasury shares as assets and were taxed upon "income" derived from dealing in their own shares. Darrell, Corporate Liquidations and the Federal Lincome Tax, 89 U. PA. L. REv. 907,912 (1941).

37 See Keefe v. Cote, 213 F.2d 651, 655 (1st Cir. 1954); Boyle v. Commissioner, 187 F.2d 557, 561 (3d Cir.), cert. denied, 342 U.S. 817 '(1951); Wall v. United 


\section{Equivalency to a Dividend?}

The genesis of the statutory section and the lack of any clear criteria as to what Congress considered relevant in determining "dividend equivalency" gave rise to a host of apparently conflicting decisions. Despite the efforts of various authors to give content to this area of the law, usually by arguing that dividend equivalency was solely a question of the proportional nature of the distribution, ${ }^{38}$ the courts have failed to adopt any such approach and as recently as 1957 a lower court referred to "the nightmarish problem that arises from the terms and court interpretations of such terms of Section $115(\mathrm{~g})$. . . . 39 However, the criteria used in determining dividend equivalency have changed with time and if all cases are not regarded as expository of "the law," it is possible to expound this development."

The cases, even after the Revenue Act of 1926, equated the conception of "dividend equivalency" to the Eisner v. Macomber ${ }^{41}$ situation which had evoked the enactment of section $201(\mathrm{~g})$. Thus it was thought that the section should be inapplicable to redemptions of stock other than dividend stock which had not been issued for a valid business purpose. ${ }^{42}$ Indeed, in the 1932 case of Pearl B. Brozm, ${ }^{43}$ the Board of Tax Appeals noted that "the only equivalence to a dividend is that the shareholders received a cash distribution from the corporation, as they would have done if a dividend had been declared and paid." 44

Because the post-1926 statutory scheme seemed no longer directed to this limited approach, the courts gradually abandoned it. ${ }^{45}$ Commissioner $v$. Estate of Bedford, ${ }^{46}$ decided under a different but related statutory provision, added a needed catalyst by. intimating that dividend equivalency should be correlated to the existence of earnings and

States, 164 F.2d 462, 465 (4th Cir. 1947) ; Harry Banner, 4 CCH Tax Ct. Mem. 342 (1945), aff'd on other grounds sub nom. Kirschenbaum v. Commissioner, 155 F.2d 23 (2d Cir.), cert. denied, 329 U.S. 726 (1946). The Second Circuit, however, may still cling to this distinction for cases arising under the 1939 Code. See Kirschenbaum v. Commissioner, supra at 24-25 (dictum). Section 317 (b) would seem to preclude this approach under the 1954 Code.

38 See, e.g., Bittner \& Redlich, supra note 2, at 460-61.

39 Wilson v. United States, 154 F. Supp. 341, 342 (N.D.N.Y. 1957), aff'd,

257 F.2d 534 (2d Cir.), cert. denied, 358 U.S. 893 (1958).

40 See Woodworth v. Commissioner, 218 F.2d 719, 723 (6th Cir. 1955)

(Stewart, J.).

41252 U.S. 189 (1920).

42 See, e.g., Patty v. Helvering, 98 F.2d 717, 719 (2d Cir. 1938) (L. Hand, J.).

The Second Circuit was perhaps the chief exponent of this limited approach.

4326 B.T.A. 901 (1932), aff'd, 69 F.2d 602 (7th Cir.), cert. denied, 293 U.S.

570 (1934).

4426 B.T.A. at 909.

45 See Flanagan v. Helvering, 116 F.2d 937, 939 (D.C. Cir. 1940).

46325 U.S. 283 (1945). 
profits. ${ }^{47}$ The terms of section 115 seemed to obviate such an equation, however, and the courts continued an approach which, while considering a prolixity of factors, ${ }^{48}$ placed primary emphasis upon the motives which prompted the distribution in question, as well as its pro rata nature. ${ }^{49}$

To divide these cases into two clearly delineated groups, the one reflecting the distribution at the shareholder level, the other at the corporate level, is an impossible task. A number of early cases, adopting the restrictive view of section 115 utilized a "corporate contraction" as evidence of a non-tax-avoidance motive. ${ }^{50}$ Among more recent cases, some can be selected which are usually classified under the rubric of corporate contraction. They seem to differ from other cases finding dividend equivalency only in the magnitude of the distribution and in the fact that the distribution-rather than being solely from current earnings-arose to some extent from the diminution of the operations or planned operations of the corporation.

In three cases, the distribution amounted to almost all the operating assets of the corporation and a large amount of the corporation's cash. In $L$. M. Lockhart, ${ }^{51}$ the sole shareholder of the Lockhart Oil Company of Texas received assets with a net value of $\$ 967,265.59$, leaving the corporation with a single rig carried at $\$ 33,938.93$ on the corporate books. The corporation had been kept in existence because the taxpayer wished to continue the corporate name and because a prior divorce agreement seemed to contemplate the corporation's continued life. The assets distributed were largely producing assets which the taxpayer hoped to immunize from the possible tort liability of a drilling operation. Judge Disney noted that the Treasury's

47 See Kirschenbaum v. Commissioner, 155 F.2d 23, 24 (2d Cir.), cert. denied, 329 U.S. 726 (1946).

48 See United States v. Fewell, 255 F.2d 496 (5th Cir. 1958); Pacific Vegetable Oil Corp. v. Commissioner, 251 F.2d 682 (9th Cir. 1957); Earle v. Woodlaw, 245 F.2d 119 (9th Cir.), cert. denied, 354 U.S. 942 (1947); Annot., 170 A.L.R. 1392 (1947).

49 See note 48 supra. The Second Circuit seems to have completed its cycle and now places very little emphasis upon motivation. See Northrup v. United States, 240 F.2d 304 (2d Cir. 1957). This so-called business-purpose approach seems to have special validity in jury cases. Probably this is because the judge is unwilling to direct a verdict and can find no other terms in which to place the case before the jury. See United States v. Fewell, supra note 48; Keefe v. Cote, 213 F.2d 651, 657 (1st Cir. 1954); Wilson v. United States, 154 F. Supp. 341, 342 (N.D.N.Y. 1957), aff'd, 257 F.2d 534 (2d Cir.), cert. denied, 358 U.S. 893 (1958); Griffin v. Jones, 53-2 U.S. Tax Cas. 48197 (W.D. Okla. 1952), aff'd, 216 F.2d 885 (10th Cir. 1954).

50 See Commissioner v. Champion, 78 F.2d 513, 514 (6th Cir. 1935); Commissioner v. Babson, 70 F.2d 304 (7th Cir.) (semble), cert. deniied, 293 U.S. 571 (1934); Commissioner v. Brown, 69 F.2d 602 (7th Cir.) (semble), cert: denied, 293 U.S. 570 (1934); Alfred E. Fuhlage, 32 B.T.A. 222, petition to review dismissed, 79 F.2d 998 (8th Cir. 1935); Robert R. Meyer, 27 B.T.A. 44 (1932), nonacq., 1934-1 Cus. Bunc. 26. But see McGuire v. Commissioner, 84 F.2d 431 (7th Cir.), cert. denied, 299 U.S. 591 (1936).

518 T.C. 436 (1947). 
definition of a dividend as a "distribution in the ordinary course of business" was not illuminating in the case, and thought that a dividend could be found in some cases where the distribution was not in the ordinary course of business. But the opinion of the court is not otherwise helpful. The transaction was denominated a partial liquidation because of the valid "business purpose" prompting distribution of the assets-here because they could be better operated as a partnership, and because the taxpayer assumed the liabilities of the corporation. Estate of Vannie E. Cook ${ }^{52}$ and Favrot v. Scofield ${ }^{53}$ are factually similar.

The majority of the cases present fact situations where a corporation has sold or distributed a large portion of its assets-usually about forty per cent of net worth. An interesting case is that of Commissioner $v$. Sullivan, ${ }^{54}$ where the corporation redeemed forty per cent of its stock pro rata. The corporation, which had never paid a regular dividend, distributed assets consisting of leases, producing wells, drilling equipment, notes of the taxpayer previously given to the corporation in the amount of $\$ 250,000$, and an account receivable of $\$ 1,050,000$. The assets distributed had a net market value of $\$ 1,259,036.27$, which exceeded the accumulated earnings. ${ }^{55}$ Subsequent to the distribution the drilling equipment was transferred to a new corporation and the remaining assets were operated in partnership form. In holding section $115(\mathrm{~g})$ inapplicable, both the Tax Court and the majority of the court of appeals emphasized that the corporation did not wish to develop the leases in question because of a prior blowout. Very little emphasis was placed upon any corporate contraction theory as such and the opinions in both courts read similarly to those cases, decided before Estate of Bedford, which had taken the narrow view of section $115(\mathrm{~g})$ 's function-although the Tax Court did note that the result followed whether regard be had to the motives and purposes of the corporation or to the net effect of the transaction. $^{56}$

Judge Rives of the Fifth Circuit in a strong dissent contended that dividend equivalency should have been found, not only because of the pro rata nature of the distribution, but also because even if the majority desired to use an approach which allowed distribution at

5213 CCH Tax Ct. Mem. 822 (1954).

53 53-1 U.S. Tax Cas. 48070 (W.D. Tex. 1953).

54210 F.2d 607 (5th Cir. 1954), affirming 17 T.C. 1420 (1952), acq. in part, 1953-2 Cun. Buls. 6.

$55 I d$. at 611 (dissenting opinion). Earnings and profits were disputed and amounted to either $\$ 905,217.95$ or $\$ 359,878.24$.

56 17 T.C. 1420,1424 (1952). 
capital gain rates when prompted by a business purpose, there was no such reason to support the distribution of the nonproducing assets.

In Samuel A. Upham, ${ }^{57}$ the Brownville Paper Company redeemed forty per cent of its outstanding stock for $\$ 160$ per share ${ }^{58}$ at a total cost of $\$ 320,000$. The reasons given for the redemption were that the corporation had been planning an expansion and that in 1941, because of the advanced age of the stockholders and the prospective sale of the corporation, this plan was abandoned. The corporation therefore sold $\$ 320,000$ worth of securities from its investment portfolio, which had been accumulated in order to finance the expansion and distributed the proceeds in a pro rata redemption. During the preceding seven years, net earnings totalled $\$ 490,429.15$ and $\$ 335,700$ had been distributed as dividends. The accumulated earnings and profits were more than sufficient to make the total distribution a dividend. This court unquestionably adopted a restrictive view of the application of section $115(\mathrm{~g})$, stating:

It is apparent that if the redemption was merely a step in a plan to distribute earnings and profits to stockholders or if it was designed for the benefit of the stockholders, the time and manner of the distribution would be essentially equivalent to a taxable dividend. . . However, if the redemption was dictated by the reasonable needs of the corporate business, section $115(\mathrm{~g})$ would not apply. ${ }^{59}$

In finding no dividend equivalency, the court emphasized the business purposes which had prompted the accumulation..$^{80}$

Heber Scowcroft Inv. Co. ${ }^{61}$ presents a case where a corporation, formed in 1893, had over a period of years reinvested earnings and profits in order to expand into a number of different operations. The first redemption of stock occurred in 1931, when twenty-five

574 T.C. 1120 (1945), acq., 1945 CuMr. BuL.. 7.

58 The price reflected the market value of the shares. 4 T.C. at 1127 .

59 Ibid.

60 The Upham case has been considered by some to be contrary to E. M. Peet, 43 B.T.A. 852 (1941). It should not necessarily be so considered. In the Peet case the corporation revised expansionary plans and proceeded to redeem 2,500 of 25,000 outstanding shares at par value $(\$ 10.00)$. The corporation had $\$ 162,602.44$ cash on hand after the pro rata redemption; despite large accumulated earnings and profits no dividends had been paid for five years; net income for the two years preceding the redemption was $\$ 26,540.28$. The relationship between recently retained earnings and the distribution in partial liquidation would facilitate a finding of dividend equivalency.

$614 \mathrm{CCH}$ Tax Ct. Mem. 755 (1945). There are other more recent cases having similar facts. Because these cases were not considered by Congress in drafting the 1954 Code, they will not be discussed within the confines of this Article. For a case which adopts a strict view, see Estate of Charles D. Chandler, 22 T.C. 1158 (1954), aff'd, 228 F.2d 909 (6th Cir. 1955) (per curiam). But see Estate of Abraham Frisch, P-H TAX CT. REP. \& MEM. DeC. II 59074 (1959). 
per cent of the stock was retired pro rata, allegedly because of funds freed when credit terms were reduced. By 1939 the company, which had originated as a wholesaler and jobber of merchandise consisting primarily of dry goods and groceries, manufactured overalls and dress goods, operated a canning business, and had retail outlets for its goods. In that year it was decided to discontinue all but the original wholesaling and jobbing operations. The articles of incorporation were amended and thirty per cent of the outstanding stock was retired pro rata at its then market value of sixty dollars per share. In all, 3,556 shares were retired for $\$ 213,360$. The stock was evidently redeemed before all the assets were sold. ${ }^{62}$ The court, impressed by the company's dividend record and the fact that "the transaction was motivated by sound business reasons," ${ }^{63}$ held for the taxpayers.

A final corporate contraction case worthy of note is Joseph $W$. Imler. ${ }^{64}$ The Imler Supply Company owned one seven-story brick building and four smaller buildings. The company, which was in the retinning and soldering business, leased the major portion of its space. In 1942 when a fire destroyed the top two floors of the main building, the company used about one-half of the insurance proceeds of $\$ 28,603$ to place a roof over the fifth floor of the building. Thereafter the company discontinued its soldering business and redeemed 300 out of 654 outstanding shares for $\$ 50$ each. At the time of the distribution the balance sheet showed "accumulated earned surplus" of $\$ 37,094.89$, but the company had operated at a net loss since 1932 and had only two profitable years during this entire period. No dividends had been paid since 1934. Judge Van Fossan, in finding for the taxpayers, emphasized that but for the fire and insurance proceeds there would have been no distribution.

When these so-called corporate contraction cases are analyzed, they seem to differ from the usual dividend cases only as to the percentage of net worth distributed and in the seemingly irrelevant fact that stock had been surrendered to the corporation. Were these holdings justified under a statute which called for dividend treatment for distributions "essentially equivalent" thereto? Perhaps their greatest support can be found in the choice of the words "partial liquidation" to denote those situations which Congress intended to favor with capital gain treatment. The statutory definition was of little aid, and the semantic connotations of the term would seem to contemplate situa-

$624 \mathrm{CCH}$ Tax Ct. Mem. 755, 757 (1945). This was a factor which harmed the taxpayer in another more recent case holding for the Commissioner. See Estate of Charles D. Chandler, supra note 61.

634 CCH Tax Ct. Mem. 755, 759 (1945).

6411 T.C. 836 (1948), acq., 1949-1 Cus. Bull. 2. 
tions such as that in Sullivan. No matter how flawless the logic of those who argued that dividend equivalency was solely a matter of determining the pro rata nature of the distribution, it is easy to see how counsel and courts were able to fall into the reasoning that a dividend was a distribution in the ordinary course of business and should be regarded as "income" both for tax and corporate parlance, while a partial liquidation involved a corporate contraction and was properly considered a "return of capital." The regulations of the Treasury, indicating that the question was largely one of "fact," did little to provide that guidance which is the hoped-for function of such regulations. Moreover, the reasoning of the courts received some support in the capital gains concept itself-since the distributions involved in a "corporate contraction" often represented earnings accrued over a period of years it might have been thought that capital gains treatment was intended. Finally, the legislative history was far from clear: the Revenue Act of 1926 which finally adopted a rational provision might have been interpreted either as adopting the pro rata approach or as intended to fulfill the more limited in terrorem purpose of preventing utilization of partial liquidations solely to avoid taxes.

Whatever the explanation for those holdings which allowed capital gains treatment for these distributions in partial liquidations, the arguments of those who regarded this line of cases as an unfortunate exception to a general rule imposing taxes at ordinary rates upon distributions from a corporation to its stockholders seem persuasive. These distributions when pro rata did seem to have the same effect as a dividend: the stockholders had each received an equal amount of cash and had surrendered an equal amount of stock; their relationship to the corporation had not changed. An approach which utilized only the factor of the pro rata nature of the distribution had all the advantages of ease of administration.

It was left to the framers of the Internal Revenue Code of 1954 to resolve these problems. Two possible avenues were open: the "corporate contraction" concept could have been rejected, or Congress could have attempted to evolve a statute which would more easily delineate those transactions intended for capital gain treatment. The latter course was chosen.

\section{SeCtion 346}

Section 346 through its definition of section 331's "partial liquidation" provides capital gain treatment in two situations: ${ }^{65}$ (a) when a

65 The statute also provides that one of a series of distributions in redemption of all the stock of the corporation is a partial liquidation. This is surely another facet of a complete liquidation. INT. REv. CODE OF 1954, §346. 
distribution in redemption of part of the stock of the corporation is not essentially equivalent to a dividend and occurs within the taxable year or succeeding taxable year in which a plan was adopted; and (b) when a distribution in redemption of part of the stock of a corporation is attributable to the corporation's ceasing to conduct, or consists of the assets of, a trade or business actively conducted throughout a five-year period immediately before the distribution and immediately after the distribution the corporation is engaged in the active conduct of a trade or business which had been actively conducted throughout a five-year period-provided that neither actively conducted business was acquired by the corporation within five years in a transaction in which gain or loss was recognized.

A distribution "not essentially equivalent to a dividend" is not a self-defining term: some effort must be made to determine what transactions Congress intended to include within the ambit of subsection (a). When the bill which later became the Internal Revenue Code of 1954 was introduced into the House of Representatives only subsection (b) was included. ${ }^{66}$ In adding subsection (a), ${ }^{67}$ the Senate Report stated:

The general language of the proposed draft would include within the definition of a partial liquidation the type of case involving the contraction of the corporate business. Such as for example, cases which hold that if the entire floor of a factory is destroyed by fire, the insurance proceeds received may be distributed pro rata to the shareholders without the imposition of a tax at the rates applicable to the distribution of a dividend, if the corporation no longer continues its operations to the same extent maintained by the destroyed facility. Voluntary bona fide contraction of the corporate business may of course also qualify to the same extent as under existing law. ${ }^{68}$

Thus the existing law of corporate contraction-whatever it may have been-was continued. Why Congress chose to continue this "law" remains to be seen. The distinction between Upham and other cases where taxes were levied at ordinary rates is not self-evident in terms of legislative purpose. Indeed, the congressional purposes which underlay the granting of capital gain treatment to those transactions meeting the so-called "objective criteria" of subsection (b) may be equally difficult to define. Perhaps some illumination of the congressional purposes can be gained by investigating those situations which Congress

66 H.R. 8300, $83 d$ Cong., 2d Sess. $\$ 336$ (1954).

67 Senate Amendments to H.R. 8300, 83d Cong., 2d Sess. §346(a) (1954).

68 S. Rep. No. 1622, 83d Cong., 2d Sess. 49 (1954). 
has defined as partial liquidations in subsection (b). Unfortunately, these objective criteria are themselves far from clear. ${ }^{69}$

The most obfuscating of these is the central core of subsection (b) : the requirement of two preexisting trades or businesses. The statute does seem to require that there be two businesses, one of which is liquidated, the other continued. Is every separate operation into which a corporation enters a trade or business which has been "actively conducted" within the meaning of section 346 ?

The treasury regulations provide that: "[A] trade or business consists of a specific existing group of activities being carried on for the purpose of earning income or profit only from such group of activities, and the activities included in such group must include every operation which forms a part, or a step in, the process of earning income or profit from such group." 70 Logically, the investment of funds in securities would seem to constitute an active business. However, the regulations specifically provide that the holding of property for investment purposes does not constitute an active business. ${ }^{71}$ Perhaps the purpose of this requirement is merely to deny partial liquidation treatment to those corporations which normally invest their idle cash in investment property. The Commissioner may have reasoned that almost every money-making operation results in funds which are temporarily idle, that these funds are often invested, and that it was not the intent of Congress to allow every distribution attributable to the sale of such assets to receive the favorable treatment allowed by section $346 .^{72}$ If such were the proper rationale supporting this exclusion, it seems that nonincidental "investment activities" if done continuously and on a large enough scale would be included within the concept of "partial liquidation."

It is not clear whether the revenue rulings have adopted this distinction. In Revenue Ruling 56-554, ${ }^{73}$ a bank, through loan foreclosures, had acquired real estate and other assets of speculative value. The real estate was leased either for grazing or for oil and gas exploration. The stock of a wholly owned subsidiary which held these assets was allowed to be spun off. In a second revenue ruling, ${ }^{74}$ allow-

69 The solecistic nature of $\$ 346$ has been dealt with at length by other authors and this Comment will not attempt to catalogue each of its vagaries. See Chommie, Section 346(a)(2): The Contraction Theory, 11 TAx L. REv. 407 (1956).

${ }_{70}$ Treas. Reg. $\$ 1.346-1$ (c) (1955), incorporating by reference Treas. Reg. $\S 1.355-1$ (c) (1955).

71 Ibid.

72 This reasoning is supported by the other category of assets excluded: land or buildings used and occupied by the owner in the operation of a trade or business. Ibid.

73 1956-2 Cunr. Burr. 198 (decided under Int. Rev. Code of 1954, § 355 ).

74 Rev. RUL. 56-557, 1956-2 CuM. Bull. 199 (decided under INT. REv. Code of 1954, §355). 
ing a bank to spin off the stock of a corporation owning certain assets, an attempt was made to distinguish between investment and noninvestment assets. The assets involved consisted of substantial amounts of real estate, mineral rights in rural land, a twenty-seven per cent interest in an insurance partnership, and the capital stock of three nonbanking corporations. All except the first were denominated investment assets, and the revenue ruling considered the question of whether the spin off could be allowed despite this fact. The spin off was permitted because the "investment assets" constituted only $20 x$ of the total net worth of $175 x$.

A few rulings seem in disagreement with the bank rulings. Revenue Ruling $57-464^{75}$ deals with five rental properties which a corporation desired to spin off. The assets consisted of: the corporation's old factory and a small office building appurtenant thereto; a two-story duplex building constructed in 1950 at a cost of $200 x$; a five-room frame house constructed in 1951 for $50 x$; and a house acquired in 1955 for $70 x$ and then occupied by the sister-in-law of the president of the corporation. These assets had a book value of $430 x$. The assets of the manufacturing corporation, including a new factory building, had a book value of $1300 x$. The service disallowed section 355 treatment on the ground that the holding of these assets did not constitute the operation of a separate business. Emphasis was placed not only upon the fact that the operation of a trade or business contemplated the payment of expenses as well as the receipt of income but also upon the circumstance that the property-while yielding a gross income of $20 x$ - yielded little net after the deduction of expenses. Moreover, the assets were seen as having been acquired either for investment or for the convenience of the employees. On the other hand, another ruling allowed a corporation engaged in selling textile products to engage in a divisive reorganization. ${ }^{76}$ The asset separated consisted of an eightstory loft building which the corporation had purchased ten years previously; for five years sixty per cent of the space had been leased; and for two years one hundred per cent of the space had been leased. Unlike previous rulings which have made mention of the expenses involved and the magnitude of the managerial activities, no mention of this was made-the ruling reveals only that the gross rental income was $\$ 135,000$ and that the net income was substantial. And in Revenue Ruling 56-512,77 a corporation engaged in the paper business also owned mining propery which it leased on a royalty basis. Only minor payroll and executive expenses had been incurred and the net

75 1957-2 Cum. Burc. 244 (decided under INT. Rev. Code of 1954, § 355). 76 Rev. Rul. 58-164, 1958-1 CuM. Bull. 184.

77 1956-2 CuM. BuLL. 173. 
income was substantial. The ruling held that the distribution of these assets would not constitute a partial liquidation. Perhaps the result turned on the fact that the assets distributed were only a portion of the assets carried on the corporate balance sheet under the heading "timberlands." However, pulp-producing property would be necessary for the operation of the paper business and the leasing of mining lands seems no more an "investment activity" here than that involved in the bank rulings.

If an attempt to rationalize these rulings results in failure, it may be because the Treasury has been unable to find any clear line delineating "investment" from the operation of a trade or business. The Treasury's efforts to distinguish what constitutes a "separate" trade or business have been but little more illuminating than the effort to define investment activities. Separateness could be considered to impose a requirement that the businesses be distinct either physically, or functionally, or both. If a corporation is engaged in the manufacture of two separate products at different factories and distributes them through different sales forces, it is obvious that the corporation is carrying on two businesses. A more difficult problem arises when the corporation carries on similar activities at different locations; this question has been squarely resolved in favor of separateness-at least where the activities at the two locations are complete within themselves. In Revenue Ruling $57-334,{ }^{78}$ a corporation organized for the purposes of building, owning, and leasing real estate held three buildings. Building $A$ yielded an annual rental of $20 x$, was acquired in 1944 , had a fair market value of $160 x$, and a mortgage of $100 x$. Building $B$, acquired in 1947, yielded $8 x$ rental, had a mortgage of $40 x$ and a fair market value of $70 x$. Building $C$ was purchased in 1952 and had a fair market value of $21 x$, a mortgage of $14 x$, and a rental of $3 x$. The corporation proposed to distribute building $A$, which was located in a different city from buildings $B$ or $C$, to its stockholders. The service ruled that the separate business requirements of section 346 had been satisfied.

Whatever may be the merits of allowing separate business treatment to functionally identical activities carried on at different locations, it is clear that extremely difficult judgments arise in attempting to apply the requirement of separateness to various fact situations. The vagaries of the Treasury in this respect have been dealt with elsewhere at length and will therefore not receive further consideration at this point. $^{78}$

78 1957-2 CuMr. Burl. 240. See also Treas. Reg. \$1.355-1(d), example 8 (1955).

79 See Young, Corporate Separations: Some Revenue Rulings Under Section 355, 71 HARV. I. REV. 843 (1958). 
Another requirement which can give rise to difficult judgments is whether the separate business has been carried on for the requisite five years. In Revenue Ruling 57-492,80 a company refining and distributing petroleum products had since 1947 engaged in exploring for oil. Drilling commenced in 1953. In 1954 when oil in commercial quantities was found a subsidiary corporation was formed. The service held that the five-year requirement had not been met since the work from 1947 to 1954 had been largely preliminary and had not been producing income. The apparent criteria offered by this revenue ruling-that the active five-year business requirement presupposes a going concern-is weakened by Revenue Ruling $57-126 .{ }^{81}$ There a cooperative fresh-fruit marketing association had done "very little fruit business from 1951 to 1956," largely because of the effect of earlier frosts. In 1951 the association began a cotton compressing operation. The service ruled that a 1957 spin off had satisfied the separate business requirement. The separate identity of the fresh-fruit division had been maintained and full-scale operations had been resumed.

It appears that section 346 has not succeeded in clarifying pre1954 law. Indeed, even determining the relation that the criteria of subsection (b) bear to subsection (a)'s more general mandate is difficult. The only proposition clearly supported is that not all pro rata distributions will be considered dividends. Subsection (b) itself, however, imposes so many requirements that it can be persuasively argued that compliance with its technicalities should be the sole route to partial liquidation treatment of pro rata distributions. Under this rationale subsection (a) would be left solely for extraordinary situations such as that in Imler. ${ }^{82}$

The present section 346 seems to have answered none of the arguments of those who did not favor the "corporate contraction" concept. The technical requirements of subsection (b) demand difficult administrative judgments and would seem to be appropriate as lines distinguishing different rates of taxation only if some rationale could be offered in their support.

It would be hoped that this rationale could be found by resort to the writings of those members of the bar most closely associated with Congress in the revision of subchapter C. Drafting of statutes within the corporate area requires a high degree of technical knowledge

80 1957-2 Cum. Bulc. 247 (decided under INT. Rev. CoDE of 1954, § 355 ).

81 1957-1 Cum. Bunc. 123 (decided under INT. Rev. Code of 1954, § 355).

82 There are other pre-1954 cases which found partial liquidations not characterized by a corporate contraction. See Brodsky, Partial Liquidation: Definition of Partial Liquidation and Rules for Determining Termination of a Business, N.Y.U. 15tr Inst. ON Fed. TAX 539 (1957). 
both of the transactions which the statutes are intended to cover and of the operation of particular statutory provisions. Those possessing this knowledge are rare and can most often be found among the members of the corporate bar. Because of this, Congress has delegated a large measure of responsibility to this group in the formulation of subchapter C. In addition to the Subchapter C Advisory Group established by Congress, the American Law Institute has been engaged in a long-range project aimed at presenting concrete proposals to revise the Internal Revenue Code. Although the membership of the AII group differs from that of the advisory group, the former's proposals are substantially identical to those of the latter. ${ }^{83}$ The proposals of the ALI, however, are fully documented and therefore provide a better basis for discussion.

\section{ALI Proposals in the Field of Partial Liguidation}

The AII has vacillated upon the proper treatment of partial liquidations. In 1952 it assumed the position that any pro rata distribution should give rise to dividend treatment. Its statement differed little from that of others who had assumed positions in opposition to the Sullivan result:

It is very doubtful if the contours of a contraction test can be prescribed with any measure of success. But even if we assume that we can define 'contraction,' what is its relevance? By hypothesis the corporation has accumulated profits and is distributing cash representing some of these profits. The corporation does not intend to conclude its existence, for the distribution is not one of a series of distributions in complete liquidation of the corporation. The shareholders remain as shareholders, their initial investment is still intact, and their relationships to the corporation and each other have not been altered. In such a setting, the distribution of cash should be treated for what it is-a distribution of profits. The activity at the corporate level which produced the cash and the motivation behind its distribution are not matters which should affect this conclusion. ${ }^{84}$

When this position was subsequently abandoned the ALI offered no reasons of tax policy or equitable taxpayer treatment to support the abandonment but merely stated that it was "felt that where a substantial part of the business operations is liquidated, the resultant

83 Compare ALI, Federal Income, Estate and Gift Tax Project, Incone TAX PROBLEMS OF CoRPoRATIONS AND SHAREHOLDERS (1958), with Hearings on Advisory Group Recommendations on Subchapters $C, J$ and $K$ of the Internal Revenne Code Before House Committee on Ways and Means, 86th Cong., 1st Sess. (1959).

84 Cohen, Surrey, Tarleau \& Warren, $A$ Technical Revision of the Federal Income Tax Treatment of Corporate Distributions to Shareholders, 52 ColuM. L. REv. 1, 37-38 (1952). 
distribution, even though pro rata, should receive capital gain treatment." 85 The Institute then indicated that such treatment was justified only where the distribution in partial liquidation bore a much closer resemblance to a complete liquidation than to an ordinary distribution. The problem for the Institute thus became "one of finding a workable statutory definition of partial liquidation embodying this approach." 80 The Institute proposed alternative criteria for events meriting contraction treatment.

Under the Institute's first approach, any distribution constituting fifty per cent of the net worth of the corporation, that was pursuant to a plan to reduce the business of the corporation and attributable to a reduction of the active business of the corporation, would be considered an event meriting capital gain treatment. ${ }^{87}$ As their second "test," the AII proposed that the five-year-separate-business requirement be retained with the proviso that the distributions attributable to the termination of the discontinued business constitute at least twenty per cent of net worth. ${ }^{88}$

In adopting a net rather than a gross asset approach, the ALI pointed out that, were a gross asset test utilized, it would be necessary to allow a portion of the liquidated assets to be applied to the liquidation of the corporate indebtedness. ${ }^{89}$ From this fact, the Institute drew the conclusion that under the gross asset approach one could inflate the corporate inventory by borrowing funds and then proceed to liquidate less than fifty per cent of the long-standing business assets of the corporation plus some of the newly acquired business assets. Since under a net-worth approach the taxpayer could presumably accomplish this same result without selling any of the long-standing assets, it is difficult to perceive how this "avoidance possibility" led to a rejection of a gross asset approach.

Having stated the rules, the ALI then sets about delineating the "active business" concept. The term is left without definition "because of the difficulty of defining with precision a test phrased in such terms." 90 Regulations are foreseen which would exclude investment activities, but would include assets not used to earn income directly, as long as the distribution was attributable to a reduction in business activities. Exactly what constitutes a reduction of business is unclear. Liquidation of a captive mine previously used to provide raw materials

85 ALI, op. cit. supra note 83, at 100 .

80 Ibid.

$87 \mathrm{Id}$. at 105-07.

88 Id. at $111-20$.

$89 \mathrm{Id}$. at $105-06$.

$80 \mathrm{Id}$. at 107. 
would not constitute such a reduction of business if raw materials were subsequently purchased from outside suppliers; discontinuance of research activities would constitute such a reduction. ${ }^{91}$. The ALI notes, however, that the "Service and the courts may perhaps tend to be lenient with this type of vague general requirement" where the fifty per cent test has been satisfied. ${ }^{22}$

The ALI group next moves to the problem of distinguishing cash which was required in the liquidated business from that which would formerly have been available for distribution..$^{93}$ They note that no satisfactory formula was found and therefore leave the development of criteria to the courts and the Service on a case by case basis. ${ }^{94}$ The ALI frankly admits that it has been unable to determine any means of deterring those who plan transactions so as to fall within the partial liquidation classification or who act to expand after the so-called contraction. ${ }^{95}$

Perhaps the greatest deficiency of the ALI proposals is the failure to articulate the reasons-policy or otherwise-for the "feelings" of those members of the Institute who favored the "corporate contraction" as an event meriting capital gains tax rates. The consequences of this failure are apparent in the proposed draft: difficult determinations are not made-they are left for resolution by the courts. Distinctions without any apparent meaningfulness are made determinative of tax consequences.

\section{Suggested Theoretical Bases for the Partial Liguidation CONCEPT}

One corollary of the cleavage between the corporation and its stockholders is that income which was earned over a period of years and reinvested in the corporation may, if distributed in a single year, result in a higher tax than would have been paid if the income of the corporation had been taxed to the stockholder when earned by the corporation. Most of the corporate contraction cases represented situations of this sort. Congress has provided for recognition of income at capital gains rates in situations not too dissimilar from the partial liquidation. Indeed, the sale of stock may present such an analogous situation.

Capital gains treatment of stock sales is not predicated solely upon considerations of mitigating the possible "bunching" of income. The 
twenty-five per cent maximum rate for capital gains is far below the ordinary tax rate of those who are most apt to realize capital gains. ${ }^{98}$ Perhaps this treatment is justified by pragmatic considerations directed to keeping the capital of those most likely to invest in new ventures in a liquid state. ${ }^{97}$ However, these considerations seem inapplicable to partial liquidations. Indeed, that justification most often advanced - that the stockholders' funds are freed for investment in new ventures ${ }^{88}$-might be better effectuated through revenue laws which operate to cause funds to be invested on the corporate level where they would most often be placed in capital rather than consumable goods. ${ }^{99}$

Justification for partial liquidations might be made by parity of reasoning with the treatment of complete liquidations. According to this argument, the liquidation of the business of a single corporation would give rise to gain to be taxed at capital rates; a single corporation with two businesses should not be treated dissimilarly, for the two businesses could have been separated in the years of their inception. The argument does not bear analysis: the liquidation concept is not predicated upon the liquidation of the "business" but of the corporation; a single corporation differs markedly from two separate corporations. Moreover, the treatment of complete liquidations as transactions to be taxed at other than ordinary income tax rates seems justified largely upon the ground that not to so treat it would give rise to undue disparity between the tax treatment of the stockholder who sold his stock shortly before the liquidation and the taxpayer who awaited the liquidation.

A final weakness in this argument-and in the present Code's approach-is the unfortunate result which its adoption is likely to have in influencing business decisions. If corporations which have "two businesses" are allowed to liquidate one business and distribute

96 Staff of Joint Economic Comm, 86Th Cong., 1st Sess., The Federai Revenue System: Facts and Problems 180 (1959).

97 See Brown, "Locked In" Problem, Jornt Comm. on tHe Economic Report, 84Th CoNG., 1st. Sess. 367 (Comm. Print 1955). 632-36.

$98 \mathrm{See}$ e.g., Remarks of Congressman Curtis, in Hearings, supra note 83, at

99 See Report of the Committee on National Debt and Taxation 148-49 (1927) (Great Britain): "[W]hen a Company saves by retaining part of its profit, the operation is smooth and simple. In the case of a progressive business the flow of capital is just in the place where it is required; it is at the growing point of industry, enabling new needs and opportunities to be met without delay as and when they arise. This is true of the new enterprising business, which may as yet be making only small profits, as well as of the established company whose ability to save large sums for development year by year has given proof of efficiency and power of continued expansion. There are cases of course where reserves are accumulated out of a caution rather than enterprise, and are invested, e.g., in the preference shares of outside concerns, but generally speaking it is true that the income tax, when it falls upon company reserves, entrenches upon a form of saving which is of special value to the community." 
funds to their shareholders at capital gain rates, the tax laws would in effect provide a reward for the diversification of corporate businesses. Whether such diversification presents the optimum mode of business operation is debatable, but most would agree that any such decision should be made upon operating rather than tax considerations. How often section 346's favorable treatment of two businesses, if thought to be a permanent addition to the tax laws, would give rise to such taxmotivated judgments is difficult to ascertain. Certainly an investor, all other things equal, would rather invest in a business such as that considered in the real estate revenue ruling ${ }^{100}$ than one which could not be so divided. Even if the two-business approach were not thought to provide this type of motivation, it is difficult logically to support such disparate degrees of shareholder fiscal responsibility upon the seemingly irrelevant ground that one corporation has two businesses and sold one of them, while another corporation had but one business of which it sold twenty per cent.

Is there any other ground which can be urged in support of preferential treatment of partial liquidations? Two arguments might be offered: first, allowing capital gain treatment of partial liquidations may have a salutory effect in giving corporations more freedom in disposing of unneeded assets; second, such treatment would take some of the pressure off the sale or merger of the entire corporation as the only sure route in certain situations to the realization of accumulated corporate earnings at capital gain rates. Both of these arguments draw their justification from the effects which such treatment might be thought to have upon shareholder actions.

Some authors have forcefully argued that revenue measures should not be concerned with regulating conduct at the primary level, but rather that this should be left to other agencies of government. ${ }^{101}$ These arguments have been formulated largely with regard to the question whether gain should be recognized in corporate mergers; however, the same contentions might well be made with regard to the above suggestions. Although one might be able to conceive of an internal revenue code which had no effect upon day-to-day conduct but merely raised revenue, it is clear that the present Code does regulate conduct in the sense that people are induced to act in certain ways because of the tax consequences attached to their actions. Thus, the problem for Congress is not simply one of whether it chooses to regulate conduct, but is-in a section 346 context-one of attempting

100 Rev. Rul. 57-334, 1957-2 CuM. BuLl. 240.

101 See, e.g., Brown, An Approach to Subchapter $C$, in House Comm. on Ways and Means, 86th Cong., 1st Sess., Tax Revision Compendum, Compendium of Papers on Broadening the Tax Base (Comm. Print 1959). 
not to place unwitting pressure upon taxpayers to select one, rather than another, of two alternative courses of action both of which have business justification.

The present Code's disparity of rates between income in the form of dividends and income realized upon the sale of stock encourages stockholders to plan their affairs in such a way that they will realize upon corporate earnings at capital gain rates. Today this can be best accomplished through reinvestment of earnings in the corporation, payment of minimal dividends, and the eventual realization of these earnings through sale of the stock. Thus, because of high rates of taxation upon dividends, the corporation may find that its stockholders would be better off through the continued operation of assets providing a minimal return than through sale of these assets and distribution of the proceeds in the form of dividends. Of course, if the corporation has some other need for the funds raised through sale of the assets, the cash will be retained in the business.

Those who desire to realize upon their investments in small corporations may have difficulty in finding purchasers. Outsiders will often be unwilling to buy a minority interest in a closed corporation, and even if the corporation is large enough that a secondary offering of stock can be made, such an offering is both difficult and expensive to market. ${ }^{102}$ Thus the sale will often be best accomplished through a merger with a larger corporation with the vendee giving only stock in exchange for the assets of the business. Traditionally, the argument has been advanced that the best means of preventing the corporate merger of the type-the small corporation merging into a much larger publicly owned entity-is to provide for the recognition of gain on such transactions by repealing the present nonrecognition provisions contained in subchapter $\mathrm{C}^{103}$ Another means would simply be to allow the stockholders to withdraw funds from their own corporation at capital gain rates.

If Congress should decide that the present Code places undue emphasis upon a corporation's retaining assets beyond the point where their retention is of real use to the business, and also desires to find an alternative route for pro rata stockholder enjoyment of accumulated corporate earnings at capital gain rates, what type of statute should be drafted for this purpose? The greatest difficulty encountered in any attempt to draft a statute dealing with partial liquidations is to prevent the partial liquidation from becoming a substitute for dividends.

102 Such an offering can cost more than $20 \%$ of the cash received for the stock. Interview With Financial Expert, in Boston, Mass., March 16, 1960.

103 See Hellerstein, Mergers, Taxes, and Realism, 71 HARv. L. REv. 254 (1957). 
It is easy to contemplate stockholders investing funds in assets providing questionable operating returns, if this investment was seen as giving rise to a sure tax advantage. Moreover, a partial liquidation will always differ from a sale of stock in that a sale represents a loss to the stockholder of his proportionate claim against all the incomeproducing assets of the corporation, while the partial liquidation will usually represent the loss of a claim against the least desirable assets of the corporation.

The tax advantages of investing cash in the expansion of the corporation rather than distributing it to the stockholders inheres in the Code's treatment of sales of stock as events giving rise to taxation at less than ordinary income rates, as well as in the fact that funds retained in the corporation are subject to tax only on the corporate level. Thus it is difficult to predict that the possibility of a partial liquidation giving rise to capital gain treatment would be the operative fact causing the corporation to invest its funds in ventures deemed unsound when not viewed through the distorting prism of taxation. However, a partial liquidation would often present a more immediate possibility than would a merger in the distant future.

It seems doubtful that a statute can stop these machinations and at the same time give some validity to the partial liquidation concept. The present statute does nothing to prevent such transactions, but only provides a mass of technicalities which may operate to trap the unwary. A general statute such as that of the pre-1954 law might be adopted, but since the distinction between partial liquidations and dividends is tenuous at best it does not seem that such a provision could be rationally applied by the courts.

The ALI's approach, requiring that some percentage of the worth of the corporation be distributed, might be utilized. By selecting fifty per cent of net worth the ALI believed that it had selected transactions requiring such a disruption of the corporation's business that the partial liquidation would not be utilized as the usual route for the distribution of earnings and profits. While this might be true for some corporations, it is certainly not true for all-for example, the real estate company involved in the revenue ruling discussed above could distribute fifty per cent of its net worth with nothing more drastic than a paper transaction. To avoid the complete abrogation of dividend taxation the statute should contain a provision which taxed at dividend rates the undistributed earnings and profits for a stated number of years preceding the partial liquidation. ${ }^{104}$ Even then it would seem that there would be those who would obtain advantages

${ }^{104} C f$. INT. Rev. Code of 1954, $\S \S 665,666$. 
from the existence of the partial liquidation. However, these advantages would be more nearly equivalent to those obtained from the sale of stock.

Should the statute have an independent requirement that there be a "true contraction" of the corporate business, or that the transaction not be planned solely to avoid the payment of taxes? Such requirements when added to the throwback approach suggested above might act as an added deterrent to those who merely accumulated funds for the purpose of later engaging in a partial liquidation. The difficulty with the latter mandate is administrative-any requirement phrased either in terms of "business purpose" or "tax-avoidance motive" is extremely difficult to administer and might often restult in erroneous court determinations. Moreover, such criteria seem antithetical to the considerations underlying a self-administered tax system. Although one should not attribute moral opaqueness to the majority of taxpayers, to require that the taxpayer report his taxes in accordance with his motivation would strain the moral fibre of even the most virtuous.

On the other hand, a limited requirement that there be a "true contraction" of the corporate business could be articulated in more nearly objective form. A lead can be taken from Estate of Charles $D$. Chandler, ${ }^{105}$ where a corporation operated a general department store consisting of a ladies' ready-to-wear department, men's department, children's department, and a piece goods department. When the manager decided to resign, the store was sold and a ladies' ready-to-wear store was opened. The old store had occupied 8,000 to 9,000 square feet and employed ten to twenty persons; the new store had 1,800 square feet of floor space and employed from four to six employees. When fifty per cent of the outstanding stock was redeemed pro rata for an amount fairly representative of its book value, the Tax Court found that this distribution was essentially equivalent to a dividend. In so finding Judge Bruce stressed that the questioned distribution had not been made possible by the sale of the store: the balance sheet revealed that the company had approximately the same amount invested in nonliquid assets before the sale as afterwards. ${ }^{106}$ Judge Bruce's holding can be questioned-the inventories of the new store were only $\$ 16,409.23$ while those of the old store had been carried at $\$ 30,412.82$ and were sold for $\$ 46,592.33$; the equation of invested capital occurred because the fixed assets of the old business had been greatly depreciated while those in the new store were carried at cost. But even if these factors should have pressed towards a finding that the liquid assets 
were required in the old business, the approach seems commendable. Under this view, partial liquidation treatment would be denied where analysis of the corporation's financial history revealed that it had been accumulating funds and that the "partial liquidation" had not acted to free funds for distribution to the stockholders. Thus, as under present law, some assets could be excluded from those which could be sold in a partial liquidation. However, contrary to the ALI's conclusions, if a corporation with captive mines decided that its business could be better operated by purchasing raw materials on the market, partial liquidation treatment should be allowed for those amounts which survive the throwback requirement.

A final problem remains: to what other provision of the Code should treatment of partial liquidations be correlated? The area most often advanced in this connection is the so-called divisive reorganization. Both the ALI and the Subchapter C Advisory Group make this correlation in their proposed formulations, ${ }^{107}$ as do the present Code and regulations. ${ }^{108} \mathrm{~A}$ divisive reorganization occurs when a single corporation distributes the stock of one or more subsidiaries to its stockholders. Before the reorganization the stockholder holds the stock of only one corporation; after the reorganization the stockholder holds the stock of two or more corporations. The similarity of this transaction to the partial liquidation rests in the fact that if the shareholders subsequently liquidate one of the corporations they have effected the same result as would have been effectuated by a partial liquidation. In general, the divisive reorganization offers a greater opportunity for tax manipulation than does the partial liquidation: under the divisive reorganization the shareholders can divide the corporate assets into separate shells; the corporations can continue to expand, accumulating income taxed only at corporate rates; complete liquidation of the corporations can then be undertaken at the moment most propitious to the shareholders. It might be argued that this same result could be arrived at through a partial liquidation followed by a reincorporation. Such would seem to be the case unless the statute providing for partial liquidations were to provide that the liquidation must be accompanied by a sale of the assets of the corporation; such a provision would be desirable. The purpose in allowing favorable treatment of partial liquidations should not be to allow the stockholders subsequently to operate the assets but rather to permit the disposal of unproductive assets by the corporation.

107 See Hearings, supra note 83; ALI, op. cit. supra note 83.

108 Compare INT. REv. CODE of 1954, \& 346, with INT. REv. CODE of 1954, § 355. Compare Treas. Reg. $\$ 1.346$ (1955), with Treas. Reg. $\$ 1.355$ (1955). 
The argument above might be inverted: because divisive reorganizations are now allowed, partial liquidations should also be allowed. But the liberal treatment accorded by the present Code to divisive reorganizations is inexplicable. The historic purpose of the divisive reorganization and of the reorganization provisions generally, has been to allow corporations to alter their forms for purposes of business efficacy. ${ }^{109}$ Perhaps the clearest, and only, area where the efficient operation of a corporation requires both the division of the corporation and the distribution of stock to the shareholders occurs when the shareholders desire to divide up the assets and subsequently operate independent of one another. Such a situation presents none of the manipulative problems of the partial liquidation. Whether there can ever be a case where efficient operation of the corporation requires a divisive reorganization and pro rata distribution of stock to the shareholders is open to question. Those who favor this tool have spoken most eloquently concerning situations where a corporation desired to insulate itself from the risk of part of its operations ${ }^{110}$-a result which can seemingly be accomplished by the use of a subsidiary corporation without the distribution of any stock to the shareholders.

\section{Conclusion}

Although one should be suspect of generalizations flowing from an analysis of a single statutory section, a few tentative hypotheses regarding the "congenital weaknesses" of the present Code can be drawn. First, it seems clear that Congress has failed to define adequately a statutory purpose in granting the partial liquidation exception to the general rule of taxation at ordinary rates. Given this lack of rationale, it is little wonder that the various revenue rulings seem inconsistent. That the partial liquidation concept should have had such a long tenure without having been either rejected or harmonized with some congressional purpose would seem to indicate either that Congress frankly intended to make this an avenue of relief from the high individual rates of taxation, or that Congress, forced to rely upon the members of the corporate bar for aid in the drafting of statutes dealing with situations as complex as those found in subchapter $\mathrm{C}$, has merely followed the recommendations of this group. Perhaps both conclusions are correct: other sections of the Code appear to have little efficacy except as avenues of escape from high individual rates of taxation; ${ }^{111}$ and the ALI itself has defined no statutory purpose.

109 See Hellerstein, supra note 103, at 254, 258-61.

110 See, e.g., Young, sipra note 79, at 858-60.

111 See, e.g., INT. REv. CoDE of 1954, \$§ 641-68, 1014. 
It is hoped that if Congress decides to perpetuate the corporate contraction as a transaction giving rise to taxation at capital gain rates some rationale will be found for this treatment and that a statute will be drawn accordingly. If section 346 merely evidences a congressional judgment that the individual rates of taxation are too high, the section should be repealed and the individual rates themselves should be adjusted. In any event, there is a basic unfairness to other taxpayers in the existence of meaningless avenues of relief which are not available to all. 